\title{
ILLEGAL IMMIGRATION AS A THREAT TO THE SAFETY OF THE REPUBLIC OF POLAND ${ }^{1}$
}

\author{
Lt Col Andrzej SOBOŃ, PhD \\ a.sobon@akademia.mil.pl \\ National Security Faculty \\ War Studies University, Warsaw, Poland
}

\author{
Lt. Marzena PIERTUNIAK, M.A. \\ marzena.pietruniak@gmail.com \\ Polish Border Guard \\ Warsaw, Poland
}

\begin{abstract}
Uncontrolled migration is one of the threats to the state, and as illegal immigration, it is a leading threat to international security. From the point of view of state security, illegal immigration is classified as "requiring caution." In the case of Poland, illegal immigration is to a considerable extent handled by organised crime of transnational reach, effectively taking the form of criminal enterprises. In the present day, differentiating between migration and exile is intricate, because the reasons behind migration are unclear and depend on numerous factors, also related to migration policies in target countries. However, for criminal enterprises, which stop at nothing to maximise their business profits, both refugees seeking refuge and migrants seeking to improve their socio-economic situation are a source of substantial financial gain. Criminal organisations generate profit by committing various crimes. This article also looks at international and national institutions combating illegal migration as a threat to the security of the Republic of Poland and Europe.
\end{abstract}

Keywords: illegal immigration, human trafficking, FRONTEX, Europol, Border Guard

1 Article was based on the scientific co-operation between authors during preparation of their master thesis, Piertuniak M., Master Thesis: Impact of Illegal Immigration on State Security of the Republic of Poland (Wptyw nielegalnej migracji na bezpieczeństwo Rzczypospolitej Polskiej), National Security Faculty of War Studies University, Warsaw 2018.

open 2 access (C) (i) (ㄷ) 2019 Andrzej Soboń, Marzena Piertuniak,

published by War Studies University, Poland

This work is licensed under the Creative Commons Attribution-NonCommercial-NoDerivatives 4.0 License. 


\section{Introduction}

To provide a comprehensive picture of what illegal immigration is, Polish legislation is based on the provisions of the Act of 6 June 1997, as amended, i.e. the Penal Code (Ustawa z dnia 6 czerwca 1997, Kodeks Karny). Article 264 specifies circumstances that must be fulfilled in order for a violation of the law and illegal immigration to occur, describing the following conditions "whoever crosses the border of the Republic of Poland in violation of the relevant regulations, with the use of violence, threats or deceit or in co-operation with other persons" or "the crossing of the border of the Republic of Poland for other persons." The definition of illegal immigration furthermore encompasses the behaviour of persons who have crossed the border and found themselves on the territory of the Republic of Poland having used illegal, forged or illicitly modified documents. Also included in the scope of illegal immigration are illegal residents, i.e. individuals entering the territory of Poland on the basis of valid documents, such as visas or residence permits, whose deadline has passed. By exceeding the authorised length of stay, such residents violate administrative regulations and are therefore considered illegal immigrants.

The fears associated with illegal migration, shared by authorities and the general public alike, are by no means unsubstantiated: illegal migration is widely associated with the illegal activity of organised criminal groups, including smuggling of migrants, drugs and weapons, human trafficking, forced labour, begging or forcing them into the sex industry. News stories have reported on the macabre methods of smuggling immigrants, stashed away in trailers equipped with a false bottom, on minibuses taking up virtually all available space notwithstanding the cargo compartment or even as items of luggage themselves; the examples of transporting immigrants in inhumane conditions are countless. It is a complex and harmful act, particularly since behind every such story there are actual human dramas - people whose lives or freedom have been in jeopardy and who have been forced to flee from their country. Unfortunately, fatal accidents are common.

The major source of inspiration for this paper has been the research carried out as part of the diploma work devoted to the topic of illegal immigration by an officer of the Border Guard. This study presents selected aspects of the work in question, which had set out to answer the underlying question concerning: threats 
posed by organised crime of illegal immigration and their effect on state security in Poland from the perspective of the Polish Border Guard. In order to provide the most comprehensive answer to the question undertaken in the study, it must be emphasised that Polish accession to the Schengen Agreement in 2007, which resulted in the opening of the internal borders of the European Zone, enabled criminal groups to intensify the effects and income from committed crimes. In addition, along with Poland's involvement in the fight against terrorism, illegal immigration has also become an instrument in the hands of terrorists, directed against the security of the Republic of Poland. The threat to citizens of our country resulting from illegal immigration is admittedly rising; however, given the gravity of the problem, it was resolved that the said problem should not be in the scope of this study with the view to future research plans, as it requires individual consideration.

\section{Illegal immigration in Poland}

Ongoing globalisation and the inherent migration affect the magnitude of migration movements. Once individuals reach the territory of Poland, they are effectively capable of moving freely across Europe. The change in the organisation of border control and the elimination of internal border crossings within the Schengen Area have brought changes in the way illegal immigration is organised. The major established immigration routes for illegal entry to Western Europe are:

- from Africa to the southern coast of Spain, France and Italy;

- from the Balkans and Turkey to Italy;

- from Asia and the Middle East through Slovakia, the Czech Republic and Poland to Austria and Germany;

- to Germany and Scandinavia via Poland.

There are several transfer channels across Poland to Western Europe, Scandinavia and America, including Ostkanal - the Asian route and Balkan route - a section of the Balkan route. The eastern route is made use of by citizens of Asian and African countries. Due to the raised security levels on the Polish border with Ukraine and Belarus, more and more migrants are attempting to enter Poland through Lithuania, Kaliningrad Region, the Czech Republic and Slovakia (Pływaczewski 
and Ilnicki 2015, p. 18). A notable example of thwarting illegal immigration is the Border Guard's action resulting in detaining 12 people - citizens of Vietnam, aged between 16 and 30, who had arrived from Ukraine to Poland on foot through the Bieszczady Mountains. Once they reached the meeting point, they got into the waiting car whose seats had been removed to increase the available space. The team of illegal immigrants was piloted by a second car, and both vehicles were driven by Slovak citizens (Gazeta Pomorska 2018). Most immigrants from Asia moving towards Western Europe begin their illegal migration in Moscow, which is an area of activity of numerous criminal groups specialised in the smuggling of people. The process of illegal transfer can be divided into particular stages, whose completion depends on the successful completion of the previous one:

- Stage 1. To Moscow. Migrants arrive by plane or ship. Head-hunters await them at airports and stations.

- Stage 2. Migrants are picked up by couriers who transport them in groups of several people to the vicinity of Kiev, Lviv and Vilnius.

- Stage 3. Other people involved transport migrants to transfer points located on the border with the Republic of Poland.

- Stage 4. In Poland. Immigrant groups are sent to the largest cities such as Warsaw, Poznań and Szczecin.

In order to prevent cheating migrants out of their money, the payment is typically made in two instalments - the first before the operation is organised, and the second only upon successful arrival at the destination. For example, the transfer fee settlement scenarios may take the following course of events:

- migrants from Vietnam pay for documents necessary for the trip from Vietnam to Russia, the outstanding amount is paid by their future employer, who deducts the payment from the migrants' earnings;

- migrants from Vietnam pay the for the transfer from Russia or Ukraine to Poland, the remaining sum is covered by the employer, who will employ the labourers and deduct the cost of the "investment" from their wages;

- migrants from Sri Lanka, India, Bangladesh, Afghanistan, Pakistan, having reached their country of destination, are usually paid by the family in the country;

- migrants from China, after reaching the target country pay for themselves, alternatively it is their family back in the country that pays. 
According to the statistical data acquired from the Intelligence and Investigation Department of the Border Guard Headquarters (Zarzad Operacyjno-Śledczy Komendy Głównej Straży Granicznej), it was in the 2-year period between 20162018 that the highest number of initiated proceedings regarding the illegal crossing of the state border was recorded. The binding legal classification of these crimes lies at the intersection with other organised-crime-related problems. In 2016, the Polish Border Guard initiated a total of 1,202 proceedings, 439 of which concerned the illegal crossing of the Polish border, and 623 involved crossing the Polish border on the basis of forged documents. In 2017, the total number of initiated proceedings was 1,158, and 338 of those concerned illegal crossing of the Polish border and 298 related to crossing the Polish border on the basis of forged documents. By 30 September 2018, a total of 780 proceedings were initiated in connection with the illegal crossing of the Polish border, of which 302 were concerned with illegal entry into the territory of Poland, 214 were offences on the basis of falsified documents and 264 against persons obtaining property or personal benefits for enabling or facilitating the stay of a migrant on the territory of the Republic of Poland against the provisions of law.

In the reported period, there was a distinct increase in border crime committed by criminal groups dealing with illegal smuggling of persons. The vast majority of crossings were made in remote areas off the beaten track, referred to in Polish as the "green border" (zielona granica), i.e. terrain border sections distinguished by the greatly diverse lie of the land covered with dense vegetation or forests. The smuggling is professionally arranged, which includes proper intelligence regarding the current situation in Poland in terms of events, holidays or days off as a precaution to minimise the risk of border controls. It is guides and people who help cross the border that constitute the key link in the chain. Guides recognise border points, route the crossing path to specific border points and further on the territory of a neighbouring country. The operating criminal groups typically include pilot cars, whose objective is to warn in advance about spotted patrols, services or other risks from a safe distance of several kilometres. Criminal groups frequently provide illegal immigrants with a range of services including arranging transport, transfer to their destination, providing temporary shelter in transit countries, offering forged documents necessary to cross borders. Migrants detained by Polish authorities may employ numerous smokescreen tactics, and are often caught not carrying documents or money. Detained at the border, they 
do not reveal their personal data, understate their age and do not admit to having a reasonable command of Polish. Above all, these tactics are aimed at extending the procedure of removal from Poland. After reaching the designated country, immigrants are left on their own. However, their subjective awareness about the absence of threats may generate a threat to native citizens. Religious and cultural differences often spark tensions between newcomers and indigenous people. The reluctance to assimilate, imposing their national and cultural customs or laws, and the disregard for the legal and cultural standards of European countries tends to widen the gap even further and does not facilitate the adaptation process.

\section{Crimes related to illegal immigration}

The steadily growing demand for an illegal stay in another country has led to the emergence of financial opportunities for organised criminal enterprises. The numbers of migrants attempting to reach the target country independently are heavily outweighed by those using paid assistance from criminal groups. In Polish law, according to Article 258 of the Criminal Code, an organised criminal group must fulfil the following conditions:

- a strict hierarchy with the leader at the top;

- at least 3 people in the group;

- group members are assigned tasks;

- it can merge with a larger group. (Ustawa z dnia 6 czerwca 1997, Kodeks Karny)

The groups are purely profit-oriented and illegal migration has become one of the key sources of substantial income for organised criminal structures (Liedel 2011, p. 25). According to Interpol, smuggling of persons is the third most-profitable crime, just behind smuggling drugs and weapons. On an international scale, the profits of organised criminal groups from human smuggling are estimated at $\$ 75$ billion per year, and it is estimated that the organising of this practice and the use of migrants is a source of income for more than 100 million people worldwide (Interpol n.d.). 


\section{Trafficking in human beings}

Whenever illegal migrants are unable to pay for services, they often become victims of trafficking. The term "White Slave Traffic" was first introduced at an international conference on anti-human trafficking treaties in Paris in 1902; however, the term "Traffic in Women and Children" was only used for the first time in 1921, and it was not until the end of the 20th century that "Trafficking in Human Beings" was specified in international law. Furthermore, it was as late as on 15 November 2000 that the "Protocol to Prevent, Suppress and Punish Trafficking in Human Beings" was adopted by the United Nations. It has since played the role of an optional protocol to the United Nations Convention on the fight against organised crime (Mazowiecka 2014, p. 15).

The Polish Penal Code defines trafficking in human beings as "recruitment, transportation, transfer, harbouring or receipt ... [using] ... violence or unlawful threat, abduction, deception, misleading, exploiting a mistake or inability to properly comprehended action taken, abuse of a dependency relationship, use of a critical position or state of helplessness, granting or accepting private financial gain, personal benefits or the promise of the said gain or benefit to a guardian or curator of another person ... for the purpose ... of exploiting the person, even with consent, in particular in prostitution, pornography or other forms of sexual exploitation, in forced labour or services, in forced begging, in slavery or in other forms of exploitation degrading human dignity, or in order to obtain cells, tissues or organs against the provisions of the Act" (Ustawa z dnia 6 czerwca 1997, Kodeks Karny).

In recent years, as a result of its activity, the Polish Border Guard has revealed numerous cases of trafficking in human beings: 2009 - 13; 2010 - 6; 2011 - 12; 2012 - 30, 2013 - 54. In addition, the police have reported cases of human trafficking in the course of investigations: 2012 - 60; 2013 - 99; 2014 - 61; 2005 - 105; 2016 - 7; 2017 - 82. These were, in particular, women and girls that fell prey to human traffickers, having accounted for $80 \%$ of all victims. Juveniles constituted about $50 \%$ of all victims (Biuro Narodów Zjednoczonych ds. narkotyków i przestępczości n.d.). 


\section{Child trafficking}

Another example of organised criminal activities is the trafficking in children as part of illegal adoption and commercial sexual exploitation of children. Child victims typically come from underprivileged backgrounds or from single mothers, who out of abject poverty are forced to sell their children in the hope and belief that they will find a better world while the profit from sales will help maintain other family members. The fate of child victims of trafficking in human beings may be dramatic in the extreme, especially regarding feeding the child pornography industry, the paedophile underground or other forms of sexual abuse. This can be seen in the case of a recently discovered Romanian criminal group in Poland that was kidnapping children and teenagers for the purpose of collecting organs for illegal transplants (Gazeta Pomorska 2018).

\section{Commercial sexual exploitation of children}

The most common and, at the same time, most profitable phenomenon is trafficking in children for the purposes of the sex industry, with two scenarios standing out: (1) the person being aware of their near future, and (2) the person being unaware of what the purpose of their trafficking is. In a scenario where people give their the consent for this type of occupation, the reality frequently dispels their initial convictions as soon as their identification documents are withheld, and the children are intimidated, tortured, or gang-raped. In the case of people unaware of their future and the nature of their work, they are immediately forced into prostitution, following a similar procedure as in the first case. (Castles and Miller 2011, p. 78) That is why educational processes are so important to ensure the broadly understood safety of children and young people (Urych 2013, Domalewska 2018) and effective teacher activities in this area (Urych 2012). 


\section{Forced labour}

Another type of crime associated with illegal immigration and trafficking in human beings is forcing individuals to work, e.g. as childminders, caring for the elderly or the sick, or in unqualified jobs. Commonly, desperate immigrants focused on taking their own fate and the fate of their families in their own hands, decide to travel to the countries of Western Europe in the hope of improving their social and living conditions and making preparations for the arrival of their families. They become indebted to traffickers and smugglers, and once they reach their destination, they are left without the means to live. As a consequence, they become victims of forced labour in exchange for organising the transfer, are forced to work in exchange for food and accommodation, or are offered the lowest pay rates, which inevitably ends up with them becoming homeless. This is the spiral of the crime intertwined with human suffering (Castles and Miller 2011, p. 75).

\section{Forced begging}

Traffickers may also run their criminal enterprise with the aim of forcing victims into begging. In this case, the most common victims are women, children and people with visible disabilities. The aggressive impudence of begging people is often dictated by the unrealistic targets set by criminal groups. In a scenario when the collected money is insufficient for the criminal group, immigrants are subjected to corporal punishment or deprived of food or accommodation. The Polish Border Guard have also reported cases in which upon arrival in Poland, mothers were forced to beg with other children rather than their own. The organisers of human trafficking would enforce obedience by intimidating mothers and threatening to harm their own children. 


\section{Trafficking in human organs}

The developments in grafting and transplant techniques have led to other related crime - trafficking in human organs and human trafficking for organs (Pływaczewski and Ilnicki 2016, p. 24), which may have different forms:

- trading own organs by impoverished people motivated by the desire to improve their living conditions;

- kidnapping children and young people for the purpose of forced organ removal for transplantation.

Internet portals and social media are relatively regularly posting organ sale or purchase offers; for instance, in the process of conducting research for this study, on 1 November 2018, three "kidney sale" advertisements were found on the website www.oglaszamy24.pl. To say nothing of the shocking subject matter of the classified advertisements themselves, the prices of the organs offered by the authors of the advertisements were no less shocking (Oglaszamy24.pl 2018).

\section{Mechanisms for combating illegal immigration}

Effective prevention and combating illegal migration requires the participation and co-operation of different entities of government administration and non-governmental organisations. In order to respond to and tackle crimes committed on immigrants by organised criminal enterprises (mainly trafficking in human beings), they should come under the scrutiny of co-operative efforts of institutions and services. One-off events are not likely to produce the expected results. Moreover, given the increase in immigration, it should be recognised that crime rates are expected to rise. According to the Colonel of the Polish Border Guard, Tomasz Semeniuk, a former Director of the Intelligence and Investigation Department of the Border Guard Headquarters (Zarzad Operacyjno-Śledczy Komendy Głównej Straży Granicznej), human trafficking is an international and transnational crime which constitutes a serious violation of human rights. This criminal activity demands intensive international co-operation, bearing in mind the manifold, multifaceted activity of criminal groups (Mazowiecka 2014, p. 19). 
The key international organisation combating illegal migration and trafficking in human beings is the United Nations, which is supported by numerous specialised units operating under human rights protection. The list of organisations operating in Europe includes: the Council of Europe; the Organisation for Security and Co-operation in Europe; the European Union; and the International Labour Organisation (Ministerstwo Spraw Zagranicznych n.d.). With respect to the fact that many major migration routes cross within the borders of the European Union or in its vicinity, the European Commission announced a communication to the European Parliament, the Council, the European Economic and Social Committee, and the Committee of Regions of 27 May 2015, entitled "EU Action Plan against migrant smuggling (2015-2020)." The fundamental assumptions of the plan concern:

- weakening the criminal networks involved in migrant smuggling through proactive financial investigations;

- setting up a contact group for EU Agencies on migrant smuggling;

- gathering and sharing information on the modus operandi of perpetrators;

- development and promotion of the knowledge-base on smuggling;

- amending Frontex agency legal basis to strengthen its role;

- encouraging transnational co-operation;

- encouraging multi-sector investigations on migrant smuggling;

- tightening co-operation between countries outside the European Union. (Komisja Europejska 2015).

On the basis of the EU Action Plan against migrant smuggling (2015-2020), the scope of activities for Frontex Agency has been expanded to include, inter alia:

- assisting Member States in training national border guard;

- assisting Member States requiring increased technical and operational assistance at external borders;

- deployment of Rapid Border Interventions Teams on borders of Member States in the event of urgent and exceptional threats resulting from e.g. mass influx of illegal immigrants;

- developing an integrated Risk Analysis Network for the ongoing development of risk assessment of illegal migration hazards (Frontex n.d.).

Having been made responsible for the performance of the above tasks, Frontex encompasses the: 
- Frontex Risk Analysis Network (FRAN) - a platform for border guard analysts, whose task is to exchange intelligence data and to create analytical and strategic reports (Frontex 2018);

- Information and Coordination Network (ICOnet) - a network handling FRAN data (Komisja Wspólnot Europejskich 2008);

- Rapid Border Intervention Teams (RABIT) for technical and operational support of Member States (Frontex 2018).

- Central Record of Available Technical Equipment (CRATE) - in which the technical capabilities of each country are entered, in case they should have to be made available to another Member State. (Lubiewski 2016, p. 78)

An important institution combating organised crime and terrorism is Europol - European Union Agency for Law Enforcement Cooperation (Europol n.d.). In 2016, Europol was established under the Regulation of the European Parliament and the EU Council No. 2016/794, regarding the European Union Agency for Law Enforcement Cooperation. It is the centre for the exchange of criminal records between Member States, and is, furthermore, an EU law enforcement agency monitoring European security levels. There are six Polish services involved in the co-operation with Europol: the Police, Border Guard, Customs Service, Internal Security Agency, Central Anti-Corruption Bureau, and General Inspector of Financial Information (Generalny Inspektor Informacji Finansowej 2018). In Poland, Europol employs over 100 analysts who play a special role in combating terrorist threats, due to the fact that the border of Poland is simultaneously the external border of the EU.

An important part in counteracting illegal immigration is played by the European database Intranet False and Authentic Documents Online - iFADO, which contains information on travel documents of residents of the European Union member states and some other European countries (Sekretariat Generalny Rady Unii Europejskiej 2014). The database may only be accessed by the control authorities during border control or other activities that require determining whether the travel document is authentic.

In Poland, the coordinator for combating trafficking in human beings is the Minister of the Interior and Administration. A Team for Combating and Preventing Trafficking in Human Beings functions in the Ministry, which was appointed by the Prime Minister in 2004. The team is composed of representatives 
of government administration entities, international and non-governmental organisations (Zespół do Spraw Zwalczania i Zapobiegania Handlowi Ludźmi 2013). In order to support and protect recognised potential victims of human trafficking, the Minister of the Interior and Administration commissioned nongovernmental organisations to carry out a public task as part of "The National Consulting and Intervention Centre for the Victims of Trafficking."

The aim of the Centre (Krajowe Centrum Interwencyjno-Konsultacyjne (KCIK) is to provide assistance to victims of trafficking, with a special emphasis on supporting victims and witnesses of trafficking in human beings and people at risk of trafficking (Krajowe Centrum Interwencyjno-Konsultacyjne dla Ofiar Handlu Ludźmi n.d.). In 2016, KCIK provided support to 200 victims, including 96 Polish citizens and 104 foreigners, in contrast to the period up to 2014, when the largest percentage of victims originated in Romania and Bulgaria; whereas in 2015-2016, these were citizens of Vietnam (2015 - 37, 2016 - 14) and Ukraine (2015 - 24, 2016 - 50) that dominated among foreigners (Ministerstwo Spraw Wewnętrznych i Administracji 2016).

In 2008, the Headquarters of the Border Guard appointed a Team for Ongoing Monitoring and Coordination of the Border Guard Actions in Preventing and Combating the Crime of Human Trafficking. The key tasks of the team are ongoing monitoring and analysis of existing cases; coordination of activities under the National Action Plan Against Trafficking in Human Beings, co-operation with the Ministry of the Interior and Administration, the Police and other institutions and organisations empowered in this regard.

\section{Summary}

Combating illegal immigration and emerging related threats demands intensive co-operation of all relevant international and domestic entities whose activity is aimed at detecting criminal enterprises and law violations, as well as maintaining high-level security. The presented research results relate to crimes engendered by illegal immigration and the activities of criminal groups, which are inseparably connected with human drama, tears, pain, suffering and, in a number of cases, with death. The paper attempted to highlight the wide range of threats that may 
lead to compromising the state security, and secondly, it examined the preventative activities of the Border Guard against threats resulting from illegal immigration.

Systematic identification, interception and elimination of criminal groups by FRONTEX, Europol, the Police and Border Guard is expected to restrain the activities of criminal networks, thus reducing the number of people illegally crossing the state border. In addition, the effectiveness of operations is strictly related to the decisive actions of the judiciary bodies, including the deportation of migrants illegally residing in Poland. Enforcing returns to the country of origin is likely to become an effective measure in discouraging illegal immigrants from undertaking long and life-threatening expeditions.

\section{References}

Castles S., Miller M. J., 2011. Migracje we wspótczesnym świecie (The Age of Migration), Wydawnictwo Naukowe PWN, Warsaw.

Domalewska, D., 2018. Problematyka migracji wyzwaniem edukacji dla bezpieczeństwa. W I. Urych (ed.) Edukacja dla bezpieczeństwa. Wspótczesne kategorie. Akademia Sztuki Wojennej, Warsaw, pp. 248-259.

Europol, Europejski Urząd Policji (Europol), n.d. [online] Available from: https://europa. eu/european-union/about-eu/agencies/europol_pl [Accessed 23 Oct 2018].

Frontex, 2018. Risk Analysis for 2018 [online] Available from: https://frontex.europa.eu/ publications/risk-analysis-for-2018-a)5nJu [Accessed 12 Oct 2018].

Frontex, n.d. [online] Available from: https://frontex.europa.eu/ [Accessed 23 October 2018].

Gazeta Pomorska, 2018. Porwania dzieci w Polce do Białego Busa? Mamy komentarz policji [online]. Available from: [Accessed: 01 Nov 2018].

Generalny Inspektor Informacji Finansowej, 2018. Aktualności [online] Available from: https://www.mf.gov.pl/ministerstwo-finansow/dzialalnosc/giif/aktualnosci [Accessed 23 Oct 2018].

Interpol, 2018 [online] Available from: https://www.interpol.int/ [Accessed 10 Oct 2018].

Komisja Europejska, Unijny plan działania na rzecz zwalczania przemytu migrantów na lata 2015-2020 COM(2015) 285 final, 2015 [online] Available from: https://eur-lex. europa.eu/legal-content/PL/TXT/?uri=CELEX\%3A52015DC0285 [Accessed 31 Oct 2018].

Komisja Wspólnot Europejskich, Sprawozdanie w sprawie oceny i przyszłego rozwoju agencji Frontex $\operatorname{COM}(2008) 67$ final, 2008 [online] Available from: https://eur-lex. 
europa.eu/legal-content/en/TXT/?uri=CELEX\%3A52008DC0067 [Accessed 12 Oct 2018].

Krajowe Centrum Interwencyjno-Konsultacyjne dla Ofiar Handlu Ludźmi, n.d. Krajowy Plan Działań Przeciwko Handlowi Ludźmi Na Lata 2016 - 2018 [online] Available from: http://www.kcik.pl/krajowy_plan.html [Accessed 26 Oct 2018].

Liedel K., 2011. Transsektorowe obszary bezpieczeństwa narodowego (Trans-sectoral areas of national security), Wydawnictwo Difin, Warsaw.

Lubiewski P., 2016. Nielegalna imigracja: zagrożenia bezpieczeństwa (Illegal immigration: security threats), part. 1, WSPOL, Szczytno

Mazowiecka L., 2014. Ofiary handlu ludźmi (Victims of human trafficking), Wolters Kluwer Polska,

Ministerstwo Spraw Wewnętrznych i Administracji, 2016. Raport o stanie bezpieczeństwa w Polsce (Report on the state of security in Poland) [Accessed 13 Oct 2018].

Ministerstwo Spraw Zagranicznych RP, n.d. Biuro Narodów Zjednoczonych ds. narkotyków i przestępczości (UNODC) [online] Available from: https://www.msz.gov.pl/pl/p/ wiedenobwe_at_s_pl/onz_org_miedzynarodowe/onz/unov/unodc [Accessed 03 Oct 2018].

Ministerstwo Spraw Zagranicznych RP, Europejski Trybunał Praw Człowieka, n.d. [online] Available from: https://www.msz.gov.pl/pl/polityka_zagraniczna/europejski_ trybunal_praw_czlowieka/ [Accessed 01 Nov 2018].

Oglaszamy24.pl - Darmowe ogłoszenia, 2018 [online] Available from: http://www. oglaszamy24.pl/szukaj/ogloszenia/sprzedam-nerke [Accessed 01 Nov 2018].

Pietraszczyk M., 2018. Imigranci organizowali nielegalną migrację, [online] Available from: https://strazgraniczna.pl/pl/aktualnosci/6565,Imigranci-organizowali-nielegalnamigracje.html [Accessed 22 Nov 2018].

Pływaczewski W., Ilnicki M. (eds.), 2016. Ochrona praw człowieka w polityce migracyjnej Polski i Unii Europejskiej (Protection of human rights in the migration policy of Poland and the European Union), Olsztyn.

Pływaczewski W., Ilnicki M. (eds.), 2015. Uchodźcy - nowe wyzwania dla bezpieczeństwa europejskiego na tle standardów praw człowieka (Refugees - new challenges for European security on the background of human rights standards) [online] Available from: http:// www.uwm.edu.pl/kryminologia/wp-content/uploads/2017/02/Uchod\%C5\%BAcynowe-wyzwania-dla-bezpiecze\%C5\%84stwa-europejskiego-na-tle-standard\%C3\%B3wpraw-cz\%C5\%82owieka-tekst.pdf. [Accessed 16 Nov 2018].

Sekretariat Generalny Rady Unii Europejskiej, 2014. Intranetowe fałszywe i autentyczne dokumenty online [online] Available from: https://publications.europa.eu/pl/ publication-detail/-/publication/86608953-fc65-46b7-8b0d-af354cfdbe82/languagepl [Accessed 22 Nov 2018].

Urych I., 2012. Autorytet nauczyciela akademickiego a odpowiedzialność, Zeszyty Naukowe AON, 1(86), pp. 278-290. 
Urych I., 2013. Wartości wychowania a bezpieczeństwo młodego człowieka, Zeszyty Naukowe AON, 1(90), pp. 227-241.

Ustawa z dnia 6 czerwca 1997 r. Kodeks Karny, (Dz. U. 1997 Nr 88 poz. 553).

Zespół do Spraw Zwalczania i Zapobiegania Handlowi Ludźmi, 2013 [online] Available from: http://handelludzmi.eu/hl/struktura-instytucjona/wspolpraca/6127,Zespol-doSpraw-Zwalczania-i-Zapobiegania-Handlowi-Ludzmi.html [Accessed 01 Nov 2018]. 